\title{
Effect of biofertilizers and phosphorus on growth parameters and yield of Cowpea (Vigna unguiculata (L.) Walp.) in sandy loam soil of Prayagraj
}

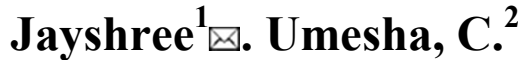

\begin{abstract}
A field experiment was carried out during Kharif, 2020 at Crop Research Farm, Department of Agronomy, Sam Higginbottom University of Agriculture, Technology and Sciences, Prayagraj (U.P) on sandy loam soil to assess the effect of biofertilizers and phosphorus on growth parameters and yield of Cowpea. The design of field experiment was Randomized block design consisting of ten treatments each replicated thrice. Experimental results showed significant increase in growth parameter viz., Plant height $(81.09 \mathrm{~cm})$, number of branches (4.87), number of nodules (53.27), plant dry weight (30.43 g/plant), crop growth rate $\left(12.59 \mathrm{~g} / \mathrm{m}^{2} / \mathrm{plant}\right)$ and yield attributing parameters $v i z$. pods/plant (14.73), seeds/ pod (8.85), 100-seed weight $(8.02 \mathrm{~g})$, seed yield $(2.62 \mathrm{t} / \mathrm{ha})$ and biological yield $(9.07 \mathrm{t} / \mathrm{ha})$ were recorded with dual inoculation of Phosphate Solubilizing Bacteria and Vesicular Arbuscular Mycorrhiza along with 55 kg phosphorus per hectare.
\end{abstract}

Key words: Biofertilizer, Biological yield, Cowpea, Growth, Phosphorus, Phosphate Solubilizing Bacteria, Seed yield, Vesicular Arbuscular Mycorrhiza

\section{Introduction}

Cowpea is an important kharif legume crop commonly known as lobia, southern pea, black eyed pea farmed throughout India for green pods, pulses, green manuring and livestock fodder. Cowpea is commonly grown in sub- tropical regions that are moderately humid and warm. It is more drought resilient however it is not tolerant to frost and waterlogging. Seeds of cowpea are nutritious and cheap source of quality protein, vitamins, iron, phosphorus as well as an excellent substitute for eggs, meat and other protein rich foods thus they are significant part of human diet. Cowpea grows predominantly in peninsular and central India. In northern India, it is grown in, Punjab, Rajasthan Haryana, Madhya Pradesh and Uttar Pradesh. During 2017 - 2018 the total coverage under cowpea in Uttar Pradesh is 23.61 lakh hectare with a production around 22.34 lakh tones (Anonymous, 2018). Phosphorus availability in Indian soils is poor to medium, however application of adequate amount of phosphorus has been recorded for higher formation of good quality

\section{Author's Address}

Department of Agronomy, Naini Agricultural Institute, Sam Higginbottom University of Agriculture, Technology and Sciences, Prayagraj-211007, Uttar Pradesh, India

E-mail.: jayshreeprabhat0@gmail.com nodules led to enhances growth and yield in legumes (Sammuria et al., 2009). Biofertilizers are used with an objective to increase the microbial population in the rhizosphere which in turn enhances the availability of nutrients for easy assimilation by plants (Sudhakar and Ranganathan, 2020). Inoculation of seed with Phosphate Solubilizing Bacteria in the rhizosphere of crop solubilize unavailable soil phosphorus and make available to plants. Vesicular arbuscular mycorrhiza (VAM) fungi improve plant growth through phosphorus nutrition. VAM is different from phosphate solubilizer as it does not solubilize the unavailable or insoluble phosphorus but assimilate phosphorus, zinc and other nutrient and translocate them into the host root along with their own need (Pandey et al., 2014). Since a large portion of the phosphorus in soil is insoluble, it is not directly available to the plants. PSB converts insoluble phosphate into soluble forms through production of organic acids, acidification, chelating and exchange reactions. Likewise, VAM develop hyphae that extend into phosphorus-available zone which is located distant from the roots, increasing the absorption surface. Hence, keeping in view all above mentioned aspects, present study was formulated to access the most suitable combination 
of biofertilizers and phosphorus for enhancing the growth parameters and yield of cowpea.

\section{Materials and Methods}

A field experiment was carried out during Kharif, 2020 at Crop Research Farm, Department of Agronomy, SHUATS, Prayagraj to assess the effect of biofertilizers and phosphorus on growth parameters and yield of Cowpea. The soil of experimental site was sandy loam in texture with low available nitrogen, low available phosphorus and medium available potassium $(190.8 \mathrm{~kg} / \mathrm{ha}$, $18.25 \mathrm{~kg} / \mathrm{ha}$ and $236.20 \mathrm{~kg} / \mathrm{ha}$, respectively). The experiment was laid out in Randomized Block Design consisting of ten treatment combinations viz., $\mathrm{T}_{1}$ - control (farmer's practice RDF i.e. NPK 25:50:20 kg/ha), $\mathrm{T}_{2}-\mathrm{PSB}+35 \mathrm{~kg} \mathrm{P} / \mathrm{ha}, \mathrm{T}_{3}-\mathrm{PSB}+45$ $\mathrm{kg} \mathrm{P} / \mathrm{ha}, \mathrm{T}_{4}-\mathrm{PSB}+55 \mathrm{~kg} \mathrm{P} / \mathrm{ha}, \mathrm{T}_{5}-\mathrm{VAM}+35 \mathrm{~kg}$ $\mathrm{P} / \mathrm{ha}, \mathrm{T}_{6}-\mathrm{VAM}+45 \mathrm{~kg} \mathrm{P} / \mathrm{ha}, \mathrm{T}_{7}-\mathrm{VAM}+55 \mathrm{~kg}$ $\mathrm{P} / \mathrm{ha}, \mathrm{T}_{8}-\mathrm{PSB}+\mathrm{VAM}+35 \mathrm{~kg} \mathrm{P} / \mathrm{ha}, \mathrm{T}_{9} \quad-$ $\mathrm{PSB}+\mathrm{VAM}+45 \mathrm{~kg} \mathrm{P} / \mathrm{ha}, \mathrm{T}_{10}-\mathrm{PSB}+\mathrm{VAM}+55 \mathrm{~kg}$ $\mathrm{P} /$ ha which were replicated thrice. Cowpea variety Pusa Dofasli was sown@25 kg/ha by maintaining spacing of $30 \mathrm{~cm} \times 10 \mathrm{~cm}$ in net plot area of $3 \mathrm{~m} \mathrm{x}$ $3 \mathrm{~m}$ on 24 June 2020 . Full dose of phosphorus was applied through SSP and cowpea seeds were treated with $10 \mathrm{ml} / \mathrm{kg}$ seed with PSB culture and $10 \mathrm{~g} / \mathrm{kg}$ seed with VAM culture and shade dried before sowing.According to the treatment blanket application of nitrogen and potassium @ $25 \mathrm{~kg} / \mathrm{ha}$ and $20 \mathrm{~kg} / \mathrm{ha}$ through urea and MOP, respectively. The observations on growth parameters i.e. plant height $(\mathrm{cm})$, number of nodules/plant, number of branches/plant, plant dry weight $(\mathrm{g})$, crop growth rate and relative growth rate were recorded from five randomly tagged plants from each plot at various growth stages whereas yield attributing parameters were recorded at harvesting stage from net plot. The recorded data were analysed statistically by ANOVA technique (Gomez and Gomez, 1984). Significant difference among the treatment mean was verified against the critical difference at five per cent level of significance.

\section{Results and Discussion}

\section{Growth parameters}

Crop growth parameters in cowpea were measured in terms of plant height $(\mathrm{cm})$, plant dry weight $(\mathrm{g})$, number of branches per plant at harvesting stage and number of nodules per plant at 45 DAS are shown in Table 1. During research trial, significantly higher plant height $(81.09 \mathrm{~cm})$ at harvest was recorded by dual seed inoculation of Phosphate Solubilizing bacteria and Vesicular Arbuscular Mycorrhiza along with $55 \mathrm{~kg}$ phosphorus per hectare as compared to other treatments. Increase in plant height due to seed inoculation with PSB and VAM which were uniformly coated resulting in better uptake and translocation of plant nutrients to growing plants. Another reason might be due to phosphate solubilizing action of PSB and phosphorus mobilizing effect of VAM fungi which boosted accessible phosphorus to the plant roots by converting insoluble phosphorus into usable form. Due to the cumulative action of two biofertilizers this attributed to better availability and uptake of phosphorus for augmenting the growth in terms of plant height, plant dry weight and number of branches (Yadav et al., 2017). Similar findings were also supported by Sammauria et al. (2009); Pramanik and Bera (2012) and Nadeem et al. (2017).With the progression of crop stage, number of branches gradually increased and significantly influenced by various treatments (Table 1). At harvest, significant and higher number of branches/plant (4.87) was recorded with dual inoculation PSB and VAM along with $55 \mathrm{~kg}$ phosphorus per hectare than other treatment combination. The probable reason might be to render insoluble and unavailable phosphorus into available form by the synergistic action of these two biofertilizer i.e. PSB+VAM. These results are in consonance with those reported by Singh et al. (2006); Dongare et al. (2016) and Prajapati et al. (2017). With the advancement of crop age, it was noticed that number of nodules was decreased at successive observations. At 45 DAS, dual seed inoculation of PSB and VAM plus $55 \mathrm{~kg}$ phosphorus per hectare has significantly increased the number of nodules/ plant (53.27) over control (Table 1). At this stage, number of nodules/plant was increased by 56.67 per cent in $\mathrm{T}_{10}$ over control. Better nodulation and dry matter production could be attributed to beneficial effect biofertilizer and phosphorus application on root proliferation and upsurge the phosphorus availability hence providing more root surface for bacterial infection and enhanced biological nitrogen fixation (Nadeem

Environment Conservation Journal 
Table 1: Effect of biofertilizers and phosphorus on growth parameters of Cowpea

\begin{tabular}{|c|c|c|c|c|c|c|}
\hline \multirow[b]{2}{*}{ Treatments } & \multicolumn{3}{|l|}{ At Harvest } & \multirow{2}{*}{$\begin{array}{l}\text { At } 45 \text { DAS } \\
\text { Nodules/ } \\
\text { Plant (No.) }\end{array}$} & \multicolumn{2}{|c|}{ During 60 - 75 DAS } \\
\hline & $\begin{array}{l}\text { Plant height } \\
\text { (cm) }\end{array}$ & $\begin{array}{l}\text { Branches/ } \\
\text { plant (No.) }\end{array}$ & $\begin{array}{l}\text { Dry } \\
\text { weight (g) }\end{array}$ & & $\begin{array}{l}\text { CGR } \\
\left(\mathrm{g} / \mathrm{m}^{2} / \text { day }\right)\end{array}$ & $\begin{array}{l}\text { RGR } \\
\text { (g/g/day) }\end{array}$ \\
\hline Control (Farmer's practice) & 68.01 & 3.67 & 21.87 & 34.00 & 9.32 & 0.0142 \\
\hline $\mathrm{PSB}+35 \mathrm{~kg} \mathrm{P} / \mathrm{ha}$ & 65.79 & 3.53 & 20.94 & 36.80 & 9.21 & 0.0148 \\
\hline $\mathrm{PSB}+45 \mathrm{~kg}$ P/ha & 75.93 & 4.40 & 26.17 & 45.67 & 11.94 & 0.0153 \\
\hline $\mathrm{PSB}+55 \mathrm{~kg} \mathrm{P} / \mathrm{ha}$ & 74.20 & 4.13 & 25.35 & 43.67 & 11.51 & 0.0153 \\
\hline $\mathrm{VAM}+35 \mathrm{~kg} \mathrm{P} / \mathrm{ha}$ & 61.84 & 3.40 & 19.82 & 33.67 & 7.46 & 0.0124 \\
\hline $\mathrm{VAM}+45 \mathrm{~kg} \mathrm{P} / \mathrm{ha}$ & 70.57 & 3.93 & 24.31 & 39.33 & 11.40 & 0.0158 \\
\hline $\mathrm{VAM}+55 \mathrm{~kg} \mathrm{P} / \mathrm{ha}$ & 71.06 & 4.07 & 24.96 & 41.53 & 11.55 & 0.0156 \\
\hline $\mathrm{PSB}+\mathrm{VAM}+35 \mathrm{~kg} \mathrm{P} / \mathrm{ha}$ & 69.58 & 3.87 & 23.74 & 40.60 & 10.66 & 0.0151 \\
\hline $\mathrm{PSB}+\mathrm{VAM}+45 \mathrm{~kg} \mathrm{P} / \mathrm{ha}$ & 77.55 & 4.60 & 28.49 & 49.00 & 12.19 & 0.0140 \\
\hline $\mathrm{PSB}+\mathrm{VAM}+55 \mathrm{~kg} \mathrm{P} / \mathrm{ha}$ & 81.09 & 4.87 & 30.43 & 53.27 & 12.59 & 0.0137 \\
\hline $\mathrm{SE}(\mathrm{m}) \pm$ & 2.40 & 0.15 & 1.66 & 2.44 & 0.73 & 0.001 \\
\hline $\mathrm{CD}(\mathrm{P}=0.05)$ & 7.15 & 0.46 & 4.95 & 7.26 & 2.17 & NS \\
\hline
\end{tabular}

Table 2: Effect of biofertilizers and phosphorus on yield attributes and yield of Cowpea

\begin{tabular}{|l|l|l|l|l|l|}
\hline Treatments & $\begin{array}{l}\text { Pods per } \\
\text { plant (No.) }\end{array}$ & $\begin{array}{l}\text { Seeds per } \\
\text { pod (No.) }\end{array}$ & $\begin{array}{l}\text { 100-seed } \\
\text { weight (g) }\end{array}$ & $\begin{array}{l}\text { Seed yield } \\
\text { (t/ha) }\end{array}$ & $\begin{array}{l}\text { Biological } \\
\text { yield (t/ha) }\end{array}$ \\
\hline Control (Farmer's practice) & 11.00 & 7.71 & 7.80 & 1.34 & 6.38 \\
\hline PSB $+35 \mathrm{~kg} \mathrm{P} / \mathrm{ha}$ & 10.73 & 6.35 & 7.79 & 1.10 & 5.63 \\
\hline $\mathrm{PSB}+45 \mathrm{~kg} \mathrm{P} / \mathrm{ha}$ & 13.20 & 8.26 & 7.89 & 2.06 & 7.83 \\
\hline $\mathrm{PSB}+55 \mathrm{~kg} \mathrm{P} / \mathrm{ha}$ & 12.67 & 8.05 & 7.86 & 1.84 & 7.52 \\
\hline $\mathrm{VAM}+35 \mathrm{~kg} \mathrm{P} / \mathrm{ha}$ & 10.27 & 6.29 & 7.77 & 1.03 & 5.33 \\
\hline $\mathrm{VAM}+45 \mathrm{~kg}$ P/ha & 11.80 & 7.84 & 7.81 & 1.61 & 6.98 \\
\hline $\mathrm{VAM}+55 \mathrm{~kg} \mathrm{P} / \mathrm{ha}$ & 12.33 & 7.92 & 7.86 & 1.76 & 7.28 \\
\hline $\mathrm{PSB}+\mathrm{VAM}+35 \mathrm{~kg} \mathrm{P} / \mathrm{ha}$ & 11.33 & 7.90 & 7.81 & 1.63 & 7.09 \\
\hline $\mathrm{PSB}+\mathrm{VAM}+45 \mathrm{~kg} \mathrm{P} / \mathrm{ha}$ & 13.87 & 8.78 & 7.94 & 2.57 & 8.89 \\
\hline $\mathrm{PSB}+\mathrm{VAM}+55 \mathrm{~kg} \mathrm{P} / \mathrm{ha}$ & 14.73 & 8.85 & 8.02 & 2.62 & 9.07 \\
\hline $\mathrm{SE}(\mathrm{m}) \pm$ & 0.44 & 0.27 & 0.03 & 0.11 & 0.35 \\
\hline $\mathrm{CD}(\mathrm{P}=0.05)$ & 1.34 & 0.81 & 0.12 & 0.34 & 1.07 \\
\hline
\end{tabular}

et al., 2017). These findings are in line with those reported by Biswas and Patra (2007); Mir et al. (2013); Jaga and Sharma (2015); Kant et al. (2016); Venkatrao et al. (2017); Yadav et al. (2017) and Singh et al. (2018). Plant dry weight increased with increasing crop age and there was significant difference among all treatment combinations at various growth stages (Table 1). The maximum dry weight $(30.43 \mathrm{~g} / \mathrm{plant})$ was recorded with seed treatment of PSB and VAM along with $55 \mathrm{~kg}$ phosphorus per hectare which showed superiority over other treatments. The probable reason might be because of increase in plant vigor as number of branches/plant and plant height with combined application of biofertilizer and phosphorus proven effective in harvesting solar energy and nutrient uptake from the soil directed to increasing photosynthetic efficiency and dry matter production per plant (Prajapati et al., 2017). These findings were also supported by Kumar and Chandra (2003); Pramanik and Singh (2003); Singh and Pareek (2003); Biswas and Patra (2007); Dongare et al. (2016) and Nadeem et al. (2017). During 60-75 DAS, significant difference among the treatments was observed and significantly higher crop growth rate $\left(12.59 \mathrm{~g} / \mathrm{m}^{2} /\right.$ day $)$ was recorded with seed treatment with Phosphate Solubilizing Bacteria and Vesicular Arbuscular Mycorrhiza along with $55 \mathrm{~kg}$ phosphorus per hectare over other treatments (Table 1). This might be due to better accumulation of dry matter throughout the plant's vegetative and reproductive phase, which enhances the physiological and metabolic activity and growth by assimilating the available nutrients at higher rate 


\section{Jayshree and Umesha}

and facilitating more photosynthesis, resulting in higher crop growth rate (Gupta et al., 2006). Similar results are in line with those of Biswas and Patra (2007) and Yadav et al. (2017). Observation regarding relative growth rate $(\mathrm{g} / \mathrm{g} / \mathrm{day})$ was found non-significant through all growth stages.

\section{Yield parameters}

The observation regarding yield and contributory attributes viz., number of pods/plant, seeds/pod, 100 seed weight, seed yield and biological yield are shown in Table 2. Significantly higher number of pods/plant (14.73), number of seeds/pod (8.85) and 100 seed weight $(8.02 \mathrm{~g})$ were recorded in coinoculation of PSB and VAM along with $55 \mathrm{~kg}$ phosphorus per hectare over other treatments. The combined inoculation recorded higher yield attributes which might be due to synergetic effect between PSB and VAM (Pramanik and Singh, 2003). The yield attributing character because of beneficial effect of PSB and VAM along with basal application of phosphorus helps in development of extensive root system to extract more water and nutrient from soil thus resulting in better plant growth and yield attributes (Pramanik and Singh, 2003). These results corroborate with those reported by of Sammauria et al. (2009); Pramanik and Bera (2012); Kumawat et al. (2013); Biswas et al. (2015); Jaga and Sharma (2017); Prajapati et al. (2017) and Yadav et al. (2017). Significantly superior seed yield $(2.62 \mathrm{t} / \mathrm{ha})$ was recorded in $\mathrm{T}_{10}$ i.e. $\mathrm{PSB}+\mathrm{VAM}+55 \mathrm{~kg} \mathrm{P} / \mathrm{ha}$ whereas, coinoculation of PSB+VAM along with $45 \mathrm{~kg}$ phosphorus per hectare, which was found

\section{References}

Anonymous, 2018. Pulses Revolution from Food to Nutritional Security, Government of India, Department of Agriculture, Cooperation \& Farmers Welfare, New Delhi.

Biswas, A. and Patra, A. P. 2007. Study on the effect of phosphorus, Vesicular Arbuscular Mychorryzae (VAM) and Phosphate Solubilizing Bacteria (PSB) on the performance of summer green gram. National Symposium on Legumes for Ecological Sustainability: Emerging Challenges and Opportunities held during 3-5 Nov. 2007 at Indian Institute of Pulses Research, Kanpur.

Biswas, P. K., Bhowmick, M. K., Kundu, M. C., Mondal, S. and Ghosh, G. K. 2015. Conjoint application of biofertilizer and phosphorous levels on growth, nodulation, nutrient uptake and productivity of lentil (Lens culinaris Medikus) in red and lateritic soils of West Bengal. Journal Crop and Weed, 11(1): 29-32. statistically on par with $T_{10}$. Similarly, application of $\mathrm{PSB}+\mathrm{VAM}+55 \mathrm{~kg} / \mathrm{ha} \mathrm{P}$ gave highest biological yield (9.07 t/ha) (Table 2). Increase in seed yield under this treatment probably due to concomitant increase in number of pods/plant, seeds/pod and 100 seed weight eventually directed to higher seed yield. Inter-relationship between seed yield and growth as well as yield attributing characters, revealed a substantial dependency of crop production on vegetative and reproductive growth of crops, which could explain the rise in biological output (Kumawat et al., 2013). These findings are in corroboration with those reported by Kant et al. (2016); Prajapati et al. (2017); Venkatrao et al. (2017); and Zafar et al. (2020).

\section{Conclusion}

Continuous usage of biofertilizer will not only reduce the need of chemical fertilizer, but it will also enhance crop yield and profit of farmer in long term use. In view of the obtained results, it could be concluded that among the studied treatments, combined seed inoculation of biofertilizers (PSB+VAM) along with $55 \mathrm{~kg}$ phosphorus per hectare was found to be more desirable that give higher growth parameters, yield attributes, seed yield and biological yield in sandy loam soil of Prayagraj. Thus, cowpea variety Pusa Dofasli and inoculation of Phosphate Solubilizing Bacteria, Vesicular Arbuscular Mycorrhiza along with phosphatic fertilizer may be recommended to apprehend higher yield of crops in this region.

Dongare, D. M., Pawar, G. R., Murumkar, S. B. and Chavan, D. A. 2016. To study the effect of different fertilizer and biofertilizer levels on growth and yield of summer greengram. International Journal of Agricultural Sciences, 12(2): 151-157.

Gomez, K. W. and Gomez, A. A. 1984. Statistical procedures for agricultural research, Second edition. John Wiley \& Sons, New York, pp 680.

Gupta, A., Sharma, G. D. and Chopra, P. 2006. Effect of biofertilizers and phosphorus levels on yield attributes, yield and quality of urdbean (Vigna mungo). Indian Journal of Agronomy, 51(20): 142-144.

Jaga, P. K. and Sharma, S. 2015. Effect of bio-fertilizer and fertilizers on productivity of soybean. Annals of Plant and Soil Research, 17(2): 171-174. 


\section{Effect of biofertilizers and phosphorus on growth parameters}

Kant, S., Kumar, A., Kumar, S., Kumar, V., Pal, Y. and Shukla, A. K. 2016. Effect of Rhizobium PSB and P-levels on Growth, Yield Attributes and Yield of Urdbean (Vigna mungo L.). Journal of pure and applied microbiology, 10(4): 3093-3098.

Kumar, M. and Chandra, R. 2003. Rhizobium and VAM inoculation effect on mungbean (Vigna radiata) with varying phosphorus levels. Legume Research, 26(4): 284287.

Kumawat, P. K., Tiwari, R. C., Golada, S. L., Garhwal, R. K. and Choudhary, R. 2013. Effect of phosphorus sources, levels and biofetilizers on yield attributes, yield and economics of black gram [Phaseolus Mungo (L.)]. Legume Research, 36: 70-73.

Mir, A. H., Lal, S. B., Salmani, M., Abid and Khan, I. 2013. Growth, yield and nutrient content of Blackgram (Vigna mungo) as influenced by Levels of phosphorus, sulphur and Phosphorus solubilizing bacteria. SAARC Journal of Agriculture, 11(1): 1-6.

Nadeem, M. A., Singh, V., Dubey, R. K., Pandey, A. K., Singh, B., Kumar, N. and Pandey, S. 2017. Influence of phosphorus and bio-fertilizers on growth and yield of cowpea [Vigna unguiculata (L.) Walp.] in acidic soil of NEH region of India. Legume Research, 1-4.

Pandey, T. D., Tiwari, R. B. and Pandey, S. A. 2014. Organic Farming. Kushal Publication and Distributors, Varanasi.

Prajapati, B. J., Gudadhe, N., Gamit, V. R. and Chhaganiya, H. J. 2017. Effect of integrated phosphorus management on growth, yield attributes and yield of chickpea. Farming $\boldsymbol{\&}$ Management, 2(1): 36-40.

Pramanik, K. and Bera, A. K. 2012. Response of biofertilizer and phytohormone on growth and yield of chick pea (Cicer arietinum L.). Journal of Crop and Weed, 8(2): 45-49.

Pramanik, K. and Singh, R. K. 2003. Effect of levels and mode of phosphorus and bio-fertilizers on chickpea under dryland conditions. Indian Journal of Agronomy, 48: 29496.
Sammauria, R., Yadav, R. S. and Nagar, K. C. 2009. Performance of clusterbean (Cyamopsis tetragonoloba) as influenced by nitrogen and phosphorus fertilization and biofertilizers in Western Rajasthan. Indian Journal of Agronomy, 54(3): 319-323.

Singh, A. K., Singh, C. K., Singh, R. K., Sarvjeet and Lavanya, G. R. 2015. Effect of phosphorus and bio fertilizer on growth and yield of greengram (Vigna radiata L.). Research in Environment and Life Sciences, 9(2): 223225.

Singh, B. and Pareek, R. G. 2003. Effect of phosphorus and biofertilizers on growth and yield of mung bean. Indian Journal of Pulses Research, 16: 31-33.

Singh, D. K. Lekh, C., Singh, K. N. and Singh, J. K. 2006. Effect of different biofertilizers in combination with chemical fertilizers on pea (Pisum sativum L.) under temperate Kashmir conditions. Environment and Ecology, 24(3): 684-686.

Sudhakar, E. and Ranganathan, P. 2020. Influence of Biofertilizer on the Growth and biochemical parameters of Arachis hypogea (L.). International Journal of Recent Scientific Research, 11(11): 40169-40171.

Venkatarao, C. V., Naga, S. R., Yadav, B. L., Koli, D. K. and Rao, J. 2017. Effect of Phosphorus and Biofertilizers on Growth and Yield of Mungbean [Vigna radiata (L.) Wilczek]. International Journal of Current Microbiology and Applied Sciences, 6(7): 3992-3997.

Yadav, M., Yadav, S. S., Kumar, S., Yadav, T. and Yadav, H. K. 2017. Effect of Phosphorus and Bio-fertilizers on Growth and Yield, of Urdbean (Vigna mungo (1.) Hepper). International Journal of Plant \& Soil Science, 18(5): 1-7.

Zafar, N., Munir, M. K., Ahmed, S. and Zafar, M. 2020. Phosphorus Solubilizing Bacteria (PSB) in combination with different Fertilizer sources to enhance yield performance of chickpea. Life Science Journal, 17(8): 8488. 